\title{
Study on Tuition Strategy for Overseas Students of Higher Education in China
}

\author{
Xiaojing Li \\ Donlinks School of Economics and Management \\ University of Science and Technology Beijing \\ Beijing, P.R. China \\ Xiaoyue Deng \\ Donlinks School of Economics and Management \\ University of Science and Technology Beijing \\ Beijing, P.R. China
}

\author{
Xuehan Wang \\ Donlinks School of Economics and Management \\ University of Science and Technology Beijing \\ Beijing, P.R. China \\ Baoming Li \\ Donlinks School of Economics and Management \\ University of Science and Technology Beijing \\ Beijing, P.R. China
}

\begin{abstract}
Recruiting overseas students can improve the visibility of the University, as well as bring considerable income. How to set tuition fees reasonably for overseas students is important to estimate the international higher education income. This paper holds that the quality of overseas students' higher education tends to be more like private goods, different from general higher education which is always considered as quasipublic goods. The tuition fees for overseas students shall be decided by the market. By analyzing the overseas students education cost, competitors, development strategy of overseas students and other factors that will affect the tuition, this paper studied the pricing strategies for higher education tuition of overseas students. This paper pointed out that at present, tuition fees for Chinese overseas students should increase a little, in order to ease the pressure of educational service trade deficit of overseas students, to achieve a smooth transition period of development.
\end{abstract}

Keywords-higher education; overseas students; influencing factors; tuition; pricing

\section{INTRODUCTION}

Recently internationalization of higher education has become a crucial part of reference index on economic globalization of a whole country. As Organization for Economic Co-operation and Development brings out in Method and Strategy Management of Developing Internationalization and System Practice, internalization has great influence on improving the fame of university at home and abroad, exploiting the advantages to the full, building communication among academic area, promoting the flow of

This thesis is the phased objectives of research on the overseas students' educational cost and cost sharing: the project of educational science of Beijing the 12th Five-Year Plan. (Project number: ADA13082) Biography: Li Xiaojing(1972-), Corresponding author, female, Han Chinese, Doctor of Management, associate professor. Research field is Financial management; Wang Xuehan(1993-),female, Han Chinese, graduate student major in accounting of Donlinks School of Economics and Management, University of Science and Technology Beijing; Deng Xiaoyue(1991-),female, Han Chinese, graduate student major in accounting of Donlinks School of Economics and Management, University of Science and Technology Beijing; Li Baoming(1980-), male, Han Chinese, vice director of International student center of University of Science and Technology Beijing, Master of Education, focused on management of international education talent, enriching the experience of students and enhancing research capabilities and so on. Educational work of recruiting international students to domestic universities has made contribution to promote communication and enhance the cooperation on educational, technological and cultural levels among our country and other countries. With the booming of the Chinese economy, China has drawn the attention of the whole world because of the potential market space and growth ability. According to statistics research of Ministry of Education points out, the number of the international students was 71294 in 2008 and 102991 in 2012. The number increases 31697 in four years and the amplification is as high as $44.5 \%$. With the trend of international education becomes more and more popular, the decision making on tuition price of those international students has been paid much attention. Students abroad to china to accept higher education is consumption exportation to us. Recruiting international students has an advantage of improving the structure of foreign trade for our country and easing the pressure of educational service trade deficit. The increasing of the number of international students not only gives impression to the outstanding educational level of the university, but also helps to enhance international prestige in order to achieve the flow of talented people at home and abroad. At the same time, self-financed international students recruitment also has been one of the sources of revenue for domestic universities. Therefore, the method of pricing the tuition of overseas students has great impact on studying on the profits of the international education project for campus and sharing the cost of international students' education. This paper firstly discusses the nature of international students 'tuition, and then studies on the strategy of pricing the tuition of abroad students coming to China based on analyzing the influence factors. 


\section{NATURE OF INTERNATIONAL STUDENTS' TUITION AND THEORY OF PRICING TUITION}

\section{A. Economic Nature of International Students' Education}

Based on Samuelsson's public goods theory, higher education service is neither pure public goods nor pure private goods. Higher education service for a fact should be specified as quasi-public product. Therefore, the cost of that education should be undertaken by both the government and the consumers. On the basis of this theory, our Ministry of Education has taken several things into consideration when making decision about pricing the higher education tuition, which are stated as below: the standard of tuition should be defined by certain part of cultivation cost per student; the tuition can be increased year by year; the process of pricing tuition should take criteria into consideration such as training cost per student, government subsidies, local developmental level and social bearing ability. Because education has a nature of publicity, spillover effect and information asymmetry, pricing the tuition has become a government action under the non-market condition. The pricing and managing tuition system in China has always been an area belonging to government price management and public finances. Unlike the nature of quasi-public goods such as regular higher education, the nature of recruiting international students is more likely a private good. The higher education service for international students has less attribute of public product and can be defined as private product. The investment on higher education can generate private profits and social profits. The family and students pay their tuition in order to gain private benefits, while government offers financial supports in order to gain social benefits once the students are graduated from school and start to make contribution to society. Right now China doesn't have large-scale immigration policy. International students are very unlikely to become Chinese citizen when graduating from school. Therefore, Chinese government has no reason to pay for international education service. General Agreement on Trade in Services (short in GATS) is one of the fundamental agreements of WTO. Among the agreement, higher education service has been listed as one of five Educational Services department, which also be pointed out as private product. Higher education services can be priced by the market and are tradable among countries. As we can see from the international students' policy of the main countries in the world, they are all treating higher education service for international students as private products. Therefore, international students' tuition should be priced by market adjustment mechanism. From the conclusions above, higher education for international students should not be in the government price control areas because of its nature as private product. On January 3rd 2014, the Ministry of Education released a draft of regulations of recruiting and training international students for public comment (announcement in Chinese here). In the draft, it firstly points out that colleges and universities can make standards of tuition on their own based on the actual situation and the related regulation. This is a huge step for our country about pricing on our own of recruiting and cultivating international students. The market adjustment mechanism, which is also referred as the invisible hand, will play a vital part in the area of pricing tuition of international students. The international students' education services exist in society as a special kind of service product. Its price has been decided by the cognitive value of consumers and the strategic positioning of universities on the condition of it covering the cost.

\section{B. The Theoretical Basis of Pricing International Students' Tuition}

Tuition pricing theory has been divided into two kinds in academic world, which are Cost Compensation Theory and Multifactor Market Deciding Theory. Cost Compensation Theory is a more popular theory for pricing tuition right now. Its core concept is that tuition is used for compensating for costs, not for gaining profits. It is worth mentioning that cost compensation theory is only suitable for pricing for higher education service provided for domestic students. As for international students coming to China to receive higher education, it is apparently not appropriate to apply to this theory. When talking about self-financed overseas students coming to China to study, it is not suitable to apply to cost compensation theory. Lu Xiaodong thinks the tuition of selffinanced overseas students coming to China to receive higher education should differentiate from tuition fee of domestic students since the basic nature of it is private product. Cost compensation policy should not be the foundation of pricing overseas students' fee. We should allow the universities and colleges to make standard on collecting fee by their own, based on market requirement, quality of education, educational concept, region and major. We should also allow the universities and colleges to gain profit from recruiting overseas students. However, Multifactor Market Deciding Theory thinks that different educating method means different product attributes and different ways of education has different characteristic of cost. The main support for students should be salary, but we don't oppose to non-salary support coming from private person. Therefore, pricing international students' education can use multifactor market deciding theory as foundation since its unique private product nature. After specifying the nature of international students' education as private product, its tuition should be decided completely by market adjustment mechanism. And we can understand that kind of educational service by the pricing regulation in commercial world. The process of pricing the international students' education fee is affected by three aspects which are external environment including international relations, national power and policy guarantee, internal environment such as ability to trade educational services including degree of internalization on lectures, teachers and managements, and the docking channels such as through colleges, agencies and overseas alumni and so on. Besides that, we did some survey and drew a logic diagram about market-oriented pricing strategy of international education tuition fee. Therefore, this paper focused on the economics nature of international education as private product, study on various influencing factors affecting international tuition fee based on multifactor deciding theory in order to give advice on pricing the tuition fee. 


\section{INFLUENCE FACTORS ANALYSIS ABOUT PRICING TUITION FEE OF INTERNATIONAL STUDENTS RECEIVING HIGHER EDUCATION}

The pricing process of international students is determined by educational cost, cognitive value, general strategy of educational output and concrete strategy of recruiting universities. According to China's national condition and the logic diagram about market-oriented pricing strategy of international education tuition fee, this paper study on the pricing process of international students' tuition fee through several influencing factors, which are educational cost per student, competing component influence, development strategy of overseas students and other factors.

\section{A. Educational Cost Per Overseas Student}

Since higher education provided for international students has a nature of private goods, it is very different from higher education provided for domestic students. The tuition charging overseas students should at least covered the cost and should gain certain amount of profits at a reasonable range. The increase of cultivating cost per student means the increase of international students' education input in order to improve the quality of higher education for international students. The upgrade of education quality will at least provide a possible space for tuition fee to increase. That is to say, in order to improve the quality of higher education provided for overseas students, it is necessary for us to increase the tuition fee for those international students who come to China to receive better higher education. Since the education cost per students has the marginal diminishing effect, the cost per student will drop as the number of international students increases. Therefore, the number of overseas students also has an effect on the pricing process of tuition fee for international students.

\section{B. Competing Component Influencing Effect}

In China, market of international students can be seen as a perfect competition market. There are mass amount of consumers (international students) and service providers (universities and colleges). Making pricing decision in such market should consider the price coming from rival competing components and competitors who provided differentiated service. The brand of colleges can be seen as a differentiated indicator which affects the amount of recruiting students and the tuition pricing decision in overseas students' education market. The expectation international students have for colleges will affect the decision whether to study abroad or not [7]. Therefore, the global ranking of colleges is a measurement index of competitiveness. The ranking affects the pricing of tuition fee through the amount of international students. For an instance, due to high international ranking, world-class universities such as Tsinghua University and Peking University can establish international projects that charges high for tuition fee to gain benefits from cultivating international students. High international ranking has a great appealing effect for international students. However, other high-class universities have less projects for international students due to the limitation of lower international ranking. Universities like these will charge a lot less.

\section{Development Strategy of Overseas Students}

Recruiting strategies of universities are different from time to time. Ji Junjie points out mutability of attributes of educational product in his research of the relation between the nature of educational product and the pricing tuition process. From the view of studying abroad, the recruiting work in China carried out very slowly before the reform and openingup policy. Among thirty years from establishment of a state to the reform and opening-up policy, the number of overseas students recruited by our country only is limited to 8000 . Since the reform and opening-up policy, China has devoted great effort to recruiting foreign students. But the communication also remained to be within the governments for a long time. The recruiting work has not developed rapidly until 1992, when the reform and opening-up policy gains great success and the cold war ends. Therefore, unlike the high tuition fee for higher education charged by some developed countries, the tuition fee in China for overseas students has been rather low. There are always trade deficit in the area of higher education service trade. Right now the strategy domestic university applies is still low-price penetration in order to attract more overseas students coming to China. However, U.S. manages to maintain pioneering advantages by its impeccable policy support, abundant resource allocation and scientific operating system, and charges high tuition fee at the same time. The enrolling number is also admirable.

\section{Other Influencing Factors}

Apart from the influencing factors stated above, we should fully consider other crucial factors when considering the pricing process of tuition fee for international students. A lot differences such as the level of opening to the outside world, the ratio of teachers and students, the education expenditure per student, GDP per capita, population, foreign investment, regional culture exist in different areas. For example, the factors such as the level of opening to the outside world, the ratio of teachers and students and GDP per capita affects the number of students more in the east region than the west region. Those factors affect the tuition fee through affecting the number of international students.

\section{TUITION STRATEGY MAKING FOR OVERSEAS STUDENTS OF HIGHER EDUCATION}

The higher education service for international students is at an early stage of growth in the product life cycle based on the amount and growth rate of international students in China. It remains to be marketing promotion period. In this kind of market environment, this paper based on the multifactor deciding theory, fully considers the influencing factors affecting the pricing process of tuition fee and puts forward the strategy of pricing the tuition fee for international students coming to China to receive higher education. At first, the education cost of educating international students should be covered by tuition fee. Besides that, the tuition fee should suitably mark up based on the cost. Increase the tuition fee by a certain amount will improve the sharing education cost mechanism for China and ease the pressure of educational service trade deficit of overseas students coming to China. Whether the tuition is charged high or low is not the 
determinant factor for international students to choose from Chinese colleges. In the year of 2011, British Council did a research on over one hundred thousand potential international students. This research is the largest scale in these kinds of researches and combined students' answers from over 200 countries. The survey found out that the chance to obtaining world-class education and the internationally accreditation degree were the crucial factors when choosing the place to study abroad. When asked to determine the most three affecting factors, $54.2 \%$ of students referred to quality, and $53.8 \%$ of students talked about career development and $51.5 \%$ of students liked the chance to live abroad and experience the unique culture. Except the global economic downturn factor, educational cost is a rather unimportant factor to consider once decided where to study for those who are very eager to study abroad. Therefore, depending on the low-price strategy seems not to be very wise option for China. Increase the tuition fee for international students by suitable amount is imperative. Improving the sharing education cost mechanism for China not only helps to ease the pressure of educational appropriations shortage, but also contributes to improving the investment structure of our government in order to push the economy to develop more steadily and continuously. At the same time, the quality of faculty and the management mechanism should also be improved. Right now our international projects made by universities and colleges appeal less especially to students from the developed countries or regions. Our universities and colleges need to optimize the educational resource structure, perfect the management mechanism for international students to laid foundation for a raise in tuition. Overseas students coming to China help to finance the universities and provide more chances for universities to create income. What's more, it ultimately changes the educational resources for colleges. Colleges and universities should increase operation rate of educational resources and build preponderant discipline and characteristic disciplines so that they can manifest their relative advantages in the market segment of international students. Due to the need of international students, the requirement of faculty's English level and the overall quality should be increased. At the same time, we should enhance the construction of our preponderant disciplines and increase the quality of the scientific research. To sum up, the price of our tuition fee for international students should be increased by a certain amount right now in order to cover the educational cost. But the tuition fee should not be overcharged to maintain the steady growth of international student number to stable the development of our international students' education.

\section{CONCLUSION}

Recruiting across the countries in the worldwide range has been a common issue for international education, which is also a general problem for every country. Recruiting international students coming to China not only booms our colleges' position in the world and increase the fame, but also brings in impressive income including tuition fee, living expenses and so on. It means a great deal for our country. As for the international students' education which is still in the developmental stage, our government should increase input and optimize educational resource structure, perfect the management mechanism. We also should enlarging recruiting propagation, increase the tuition suitably in order to increase the number of international students and cover the educational cost at the same time, to make sure the international education develops steadily.

\section{REFERENCES}

[1] Verbik L, Lasanowski V. International student mobility: Patterns and trends[J]. World Education News and Reviews, 2007,20(10):1-16.

[2] Liu, C., Kong, S., Ling, Z., \&Yang, A.(2013). Study on standard of tuition in higher education. Lecture Notes in Electrical Engineering, 219 , 3-11.

[3] Feng, C.H., \&Liu, Y.(2010). Discussion of China's higher education tuition standardin the state of game. Artificial Intelligence and Education (ICAIE), 2010 International Conference on (pp.28-32).

[4] Hemelt, S. W., \& Marcotte, D. E. (2008). Rising tuition and enrollment in public higher education. Iza Discussion Papers.

[5] Wang, W., Du, J., Wang, T., \& Zhang, A. (2010). Study on the Tuition Standard in China Higher Education.. E-Business and E-Government (ICEE), 2010 International Conference on (pp.5279-5282). IEEE.

[6] Xie, L. B., Zhang, Y. B., \& Wang, Z. W. (2010). The study of the higher education tuition fees standard. Second International Workshop on Education Technology \& Computer Science, 2(3), 391-394.

[7] Jia-Min, N. I. (2013). A study on the tuition standard of public colleges and universities in china. Journal of Ningbo University. 